\title{
Temporomandibular disorders among wind musical instrument players: an integrative review
}

\author{
Carlos José Santos Da Silva ${ }^{1}$, Patricia Valério ${ }^{2}$, Israel Júnior Borges do Nascimento ${ }^{3}$, \\ Juliana Araújo Da Silva Simoura ${ }^{4}$ \\ ${ }^{1}$ School of Dentistry, Faculdade de Ciências e Tecnologia da Bahia, Alagoinhas, Bahia, Brazil \\ ${ }^{1}$ Department of Public Administration, State University of Bahia, Salvador, Bahia, Brazil \\ ${ }^{1}$ CJS da Silva Dental Laboratory, Entre Rios, Bahia, Brazil \\ ${ }^{2}$ Department of Physiology and Biophysics, Institute of Biological Sciences, Federal University of Minas \\ Gerais, Belo Horizonte, Minas Gerais, Brazil \\ ${ }^{2}$ Patricia Valerio Institute, Belo Horizonte, Minas Gerais, Brazil \\ ${ }^{3}$ University Hospital and School of Medicine, Universidade Federal de Minas Gerais, \\ Belo Horizonte, Minas Gerais 30130-100, Brazil \\ ${ }^{3}$ Department of Internal Medicine, School of Medicine, Medical College of Wisconsin, \\ Milwaukee, Wisconsin, USA \\ ${ }^{4}$ School of Dentistry, Faculdade de Santo Antônio, Alagoinhas, Bahia, Brazil \\ ${ }^{4}$ School of Dentistry, Faculdade de Ciências e Tecnologia da Bahia, Alagoinhas, Bahia, Brazil \\ ${ }^{1}$ Corresponding author \\ E-mail: ${ }^{1}$ carlosortopedi@gmail.com, ${ }^{2}$ patricia.valerio@terra.com.br, ${ }^{3}$ israeljbn@ufmg.br, \\ 4julianasimoura.uefs@gmail.com
}

Received 10 May 2021; accepted 6 June 2021

DOI https://doi.org/10.21595/jfocg.2021.22041

Check for updates

Copyright $(2021$ Carlos José Santos Da Silva, et al. This is an open access article distributed under the Creative Commons Attribution License, which permits unrestricted use, distribution, and reproduction in any medium, provided the original work is properly cited.

\begin{abstract}
Dysfunction of the stomatognathic apparatus is a disturbance of the biomechanics of the masticatory system and craniofacial structure, usually generated by tissue damage of its main components (temporomandibular, neuromuscular, and dental-occlusal system, besides in the craniocervical spine) when the morphofunctional adaptability is exceeded. Musical activity is well-known as one of the most complex activities executed by the human musculoskeletal system, as practitioners require to adopt a non-physiological posture. Therefore, by performing an integrative review of the available literature, this study aimed to investigate the potential relationship between temporomandibular disorders and the practice of wind musical instruments. We included peer-reviewed primary studies published in the last ten years, either in English, Portuguese, or Spanish, and with a full-text available. We searched four databases (PubMed, LILACS, Scielo, and Portal Capes), using a specific search strategy using the terms "wind instrument players", "oral parafunction", and "temporomandibular disorders". We excluded articles published before 2011, studies that did not correlate temporomandibular disorders with wind music practice, as well as studies without a full text. Overall, the search retrieved ten primary studies, including 3,206 amateur and professional wind instrument players. Included studies were essentially cross-sectional studies $(n=8)$ and case-control studies $(n=2)$. The most common signs and symptoms of temporomandibular disorder and deleterious oral habits among wind players were crackling and popping sounds of the temporomandibular joint, headache, should and neck pain, mouth opening limitation, and temporomandibular joint pain. Three studies identified factors that were statistically associated with the development of temporomandibular disorders (presence of temporomandibular pain, mouthpiece pressure, and higher distance of mandible protrusion). Although we have observed a high prevalence of temporomandibular diseases among musicians who play wind musical instruments, further research is required to clarify better variables and risk factors associated with developing several systemic and oral-related diseases among these individuals.
\end{abstract}

Keywords: wind musical instrument players, oral parafunction; temporomandibular disorders. 


\section{Introduction}

The stomatognathic system is a multi-functional and complex system involved in several functional tasks (sucking, chewing, swallowing, breathing, and speech functions) and is associated with various disturbances or diseases [1], [2]. The dysfunction of this system is characterized as a disturbance of the biomechanics of the masticatory system and craniofacial unit, frequently caused by tissue damage in any of its functional elements when the morphofunctional adaptability of associated tissues is compromised. Defective components might be the temporomandibular, neuromuscular, or dental-occlusal system, as well as the craniocervical spine [2]. Notably, temporomandibular dysfunction is classified as a stomatognathic system disorder, which encompasses signs and symptoms including crackling and popping sound in the ear, limited mouth opening, pain in masticatory muscles and around the jaw area, tinnitus, pain around the ear area, and headache [3]. Generally, these before-mentioned set of clinical signs and symptoms frequently occur during activation of muscles of mastication, muscles of the head, neck, and temporomandibular joints [4].

Over the last number of years, some habits have been proven to interfere with oral health status and performance negatively and affect attached structures, causing or exacerbating temporomandibular disorder [5], [6]. Although the available literature of the etiology of temporomandibular dysfunction is still poorly understood, playing a musical instrument that overloads the stomatognathic system and requires a long-term adoption of a non-physiological posture has been suggested to be a significant etiological factor of temporomandibular dysfunction [7], [8]. Particularly, wind instrument musicians emerged as significantly affected individuals, primarily because they must continuously use face, jaw, and orofacial muscles to generate sound, leading to increased tension in the masticatory muscles and the temporomandibular joint [7]. Even though a previous non-systematic review of the literature showed a probable relationship between the practice of musical instruments and temporomandibular disorder, the study did not precisely evaluate the possible association of temporomandibular dysfunction and playing a wind musical instrument [9]. Therefore, we aimed to review the available body of literature on the potential association between playing a wind musical instrument and the occurrence of temporomandibular disorder and evaluate the consequences from the prolonged use of these instruments to temporomandibular joint disorders. Furthermore, we assessed the craniofacial impact of playing wind instruments, including the effect on the temporomandibular joint.

\section{Methodology}

\subsection{Search strategy}

An integrative review is a well-known methodology that adequately provides a synthesis of scientific knowledge and suitability of relevant studies in daily practice [10], [11]. It might systematically include clinical trials or non-experimental studies developed about a specific research question. We followed three particular guidelines for performing an integrative review [10]-[12]. Thus, we searched four public scientific databases/virtual libraries (PubMed, Latin American and Caribbean Health Sciences Literature, Portal Capes, and Scielo) to identify potentially eligible studies. We considered only studies published between January 2009 and January 2020, using the keywords and medical subject headings "wind instrument players", "oral parafunction", and "temporomandibular disorders".

\subsection{Inclusion and exclusion criteria}

Primary studies were deemed eligible for inclusion if they met the following specific criteria: a) were published between January 2009 and January 2020; b) were primarily written in English, Spanish, and Portuguese; c) full texts were available without associated subscription fees; 
d) directly evaluated the association between playing a wind instrument and temporomandibular dysfunction.

Studies were excluded a) if a study was published before January 2009 and after January 2020; b) if there was only an abstract available; c) were a duplication from another overlapping study (in which only the most complete and detailed study was included); and d) if the study did not precisely assess the direct relationship of playing a wind instrument and temporomandibular dysfunction. Although review studies were not eligible for inclusion in this study, the references list was examined thoroughly. If a citation met the predefined study criteria, it was included.

\subsection{Data extraction and synthesis}

Following the first and second-phase screening, data were extracted from each eligible primary study, including sample characteristics and sample size, year of publication, study design, journals' impact factor, and main study objective. Furthermore, we extracted results associated with the leading signs and symptoms of temporomandibular disorder and deleterious oral habits among wind musical instrument players, along with statistical findings to address the hypothesis of the potential relationship between playing a wind instrument and the existence of temporomandibular disorder signs and symptoms.

Extracted data were collated into an excel spreadsheet and the second author (JASS) rechecked imported data accuracy for inclusion. Finally, we created a summary of findings table based on each included study to summarize the overall findings.

\section{Results}

The integrative review herein presented was performed to investigate the possible association between playing wind musical instruments and the presence of temporomandibular dysfunction. Overall, the database search retrieved 40 potentially relevant articles. However, after rigorous assessment of title, abstracts, and short-listed studies, only ten primary studies were included in this integrative review (Fig. 1) [7], [13]-[21]. The studies eligible for inclusion were conducted in Brazil $(n=3)$, Japan $(n=2)$, Germany $(n=2)$, The Netherlands $(n=1)$, Portugal $(n=1)$, and The United States of America $(n=1)$. Out of the ten articles, eight were quanti-qualitative investigations that used a cross-section study design [7], [13], [16]-[21], and two were quantitative studies that used a case-control design [14], [15]. After cross-checking the reference list of selected full-text studies, no additional publication was identified.

\subsection{Participants and main objectives}

Table 1 summarizes the ten included studies and enrolled participants' characteristics. Across the ten included studies ( $n=3,206$ participants), there were considerable heterogeneity in the type of participants (some studies enrolled professional musicians, while others had non-professional practitioners). One study did not describe primary participants' characteristics [21].

Table 1. Study characteristics of the included papers

\begin{tabular}{|c|c|c|c|c|}
\hline $\begin{array}{l}\text { Author name } \\
\text { Publication } \\
\text { Year Journal } \\
\quad \text { IF }\end{array}$ & Study objective & $\begin{array}{l}\text { Number of } \\
\text { participants }\end{array}$ & $\begin{array}{c}\text { Signs and symptoms of } \\
\text { TMD and deleterious oral } \\
\text { habits }\end{array}$ & $\begin{array}{c}\text { Was there an } \\
\text { association between } \\
\text { playing wind } \\
\text { instruments and } \\
\text { developing TMD? }\end{array}$ \\
\hline $\begin{array}{c}\text { Stechman et } \\
\text { al. } \\
\text { 2009* }\end{array}$ & $\begin{array}{l}\text { Verify the prevalence of sign } \\
\text { and symptoms of } \\
\text { temporomandibular } \\
\text { dysfunction in professional } \\
\text { musicians }\end{array}$ & 70 & $\begin{array}{c}\text { Stress and anxiety } \\
(61.42 \%) \\
\text { Teeth grinding and/or teeth } \\
\text { pressing }(42.3 \%) \\
\text { TMJ pain }(25 \%) \\
\end{array}$ & No \\
\hline
\end{tabular}




\begin{tabular}{|c|c|c|c|c|}
\hline & & & $\begin{array}{c}\text { TMJ sound }(42 \%) \\
\text { Auricular plenitude }(40 \%) \\
\text { Tinnitus }(35 \%) \\
\end{array}$ & \\
\hline $\begin{array}{c}\text { Nishiyama et } \\
\text { al. } \\
2016 \dagger\end{array}$ & $\begin{array}{c}\text { Investigate associations } \\
\text { between the risk of TMD and } \\
\text { playing wind instruments in } \\
\text { non-professional players }\end{array}$ & 72 & $\begin{array}{l}\text { Mouthpiece pressure } \\
(47.5 \%)\end{array}$ & $\begin{array}{c}\text { Yes } \\
\text { Mouthpiece } \\
\text { pressure was found } \\
\text { to be a significant } \\
\text { factor contributing } \\
\text { to a high risk of } \\
\text { TMD (OR 3.31; } \\
95 \% \text { CI 1.12-9.79) }\end{array}$ \\
\hline $\begin{array}{c}\text { Pampel et al. } \\
2013 \dagger\end{array}$ & $\begin{array}{l}\text { Examine evidence that TMD } \\
\text { constitute an occupational } \\
\text { disease in wind musicians }\end{array}$ & 102 & $\begin{array}{c}\text { Deleterious oral } \\
\text { habits }(100 \%) \\
\text { Preauricular muscle pain }\end{array}$ & \begin{tabular}{|c|} 
Yes \\
Wind instrument \\
players who had a \\
higher distance of \\
mandible protrusion \\
had a significantly \\
greater risk to \\
develop TMD \\
\end{tabular} \\
\hline $\begin{array}{l}\text { Selms et al. } \\
2019 *\end{array}$ & $\begin{array}{c}\text { Assess the prevalence of and } \\
\text { risk indicators for symptoms } \\
\text { of TMD, pain in the neck or } \\
\text { shoulder, and headache } \\
\text { among musicians }\end{array}$ & 1,470 & $\begin{array}{l}\text { Headache }(42.5 \%) \\
\text { TMJ sounds }(18.3 \%)\end{array}$ & No \\
\hline $\begin{array}{c}\text { Steinmetz et } \\
\text { al. } \\
2013 *\end{array}$ & $\begin{array}{l}\text { Evaluate the frequency of } \\
\text { craniomandibular disorders } \\
\text { and its relation to } \\
\text { musculoskeletal pain in } \\
\text { various body regions }\end{array}$ & 408 & $\begin{array}{c}\text { TMJ pain }(34 \%) \\
\text { General facial pain }(27 \%) \\
\text { Jaw clenching }(33 \%) \\
\text { Jaw locking }(11 \%)\end{array}$ & $\begin{array}{l}\text { Yes } \\
\text { TMJ pain and jaw } \\
\text { clenching and } \\
\text { locking }\end{array}$ \\
\hline $\begin{array}{l}\text { Jang et al. } \\
2016^{*}\end{array}$ & $\begin{array}{l}\text { Investigate the clinical signs } \\
\text { and subjective symptoms of } \\
\text { TMD in a large number of } \\
\text { instrumentalists objectively }\end{array}$ & 739 & $\begin{array}{l}\text { TMJ pain and myalgia } \\
\qquad(61.3 \%)\end{array}$ & $\begin{array}{c}\text { Yes } \\
\text { Myalgia }\end{array}$ \\
\hline $\begin{array}{l}\text { Leonardi et } \\
\text { al. } \\
2020^{*}\end{array}$ & $\begin{array}{l}\text { Assess the prevalence of } \\
\text { TMD and associated risk } \\
\text { factors among wind } \\
\text { instrument player }\end{array}$ & 35 & $\begin{array}{c}\text { Disc displacement }(34.2 \%) \\
\text { Muscular disturbances } \\
(14.2 \%) \\
\text { Joint disorders }(8.5 \%) \\
\end{array}$ & No \\
\hline $\begin{array}{c}\text { Yasuda et al. } \\
2016^{*}\end{array}$ & $\begin{array}{l}\text { Investigate if playing wind } \\
\text { instruments has adverse } \\
\text { effects on musculoskeletal } \\
\text { functions among primary } \\
\text { students } \\
\end{array}$ & 210 & $\begin{array}{l}\text { Increased muscle activity } \\
\text { (masseter, } \\
\text { sternocleidomastoid, } \\
\text { cervical, and trapezius) }\end{array}$ & $\begin{array}{l}\text { Yes } \\
\text { Playing woodwind } \\
\text { or brasswind }\end{array}$ \\
\hline $\begin{array}{c}\text { Barbosa et } \\
\text { al. } \\
2016^{*}\end{array}$ & $\begin{array}{c}\text { Determine the relationship } \\
\text { between playing a musical } \\
\text { instrument and the } \\
\text { development of TMD }\end{array}$ & 100 & $\begin{array}{c}\text { Facial pain }(40 \%) \\
\text { Headache }(15 \%) \\
\text { Pain when opening the } \\
\text { mouth and chewing } \\
(37.5 \%) \\
\text { Mandible clenching } \\
(17.5 \%)\end{array}$ & No \\
\hline $\begin{array}{c}\text { Lacerda et al. } \\
2015^{*}\end{array}$ & $\begin{array}{l}\text { Assess the prevalence of } \\
\text { TMD among wind } \\
\text { instrument players and } \\
\text { determine the relationship } \\
\text { between playing a wind } \\
\text { instrument and the } \\
\text { development of TMD }\end{array}$ & 41 & $\begin{array}{c}\text { Disc displacement }(29.3 \%) \\
\text { Disc displacement with } \\
\text { reduction }(14.6 \%) \\
\text { Degenerative disorders } \\
(43.9 \%) \\
\text { Osteoarthritis }(24.4 \%) \\
\text { Osteoarthrosis }(19.5 \%)\end{array}$ & $\begin{array}{l}\text { Yes } \\
\text { Gender, age, and } \\
\text { the interaction age } \\
\text { and years of } \\
\text { instrument practice }\end{array}$ \\
\hline
\end{tabular}


stands for "Temporomandibular Disorder", TMJ stands for "Temporomandibular Joint", * Observational cross-sectional studies, $\uparrow$ Observational case-control studies

As far as the primary studies objectives concerned, studies essentially were designed to evaluate: 1. The prevalence of signs and symptoms of temporomandibular disorder among individuals who played wind instruments; 2 . The relative risk or odds ratio of wind instrument players develops temporomandibular disorder; 3 . The most frequently reported signs, symptoms, and complaints of individuals who play wind instruments; and 4. The evidence of correlating the temporomandibular dysfunction as an occupational disease.

\subsection{Summary of findings}

Temporomandibular joint pain (prevalence ranging from $25 \%$ to $61.3 \%$ ), lips pain, and ringing in the ear sensation (tinnitus, prevalence of $35 \%$ ) were the most reported across included studies regarding observed signs and symptoms of temporomandibular disorder among wind instrument players. Moreover, headache (prevalence ranging from $15 \%$ to $42.5 \%$ ), temporomandibular sounds (prevalence ranging from $18.3 \%$ to $42 \%$ ), facial pain (prevalence ranging from $27 \%$ to $40 \%$ ), teeth grinding (prevalence of $42.5 \%$ ), jaw locking (prevalence of $11 \%$ ), and increased stress/anxiety (prevalence of $61.42 \%$ ) were frequently reported. Detailed information related to signs and symptoms reported by wind instrument players is shown in Table 1.

Considering the before-mentioned signs and symptoms, wind instrument players who reported playing-related problems, temporomandibular pain [7], mouthpiece pressure [14], and a higher distance of mandible protrusion [15] had a significantly greater risk to develop temporomandibular disorders compared to non-players. Furthermore, one study refers to mouthpiece pressure as a significant factor contributing to a high risk of temporomandibular disorder (odds ratio (OR), 3.31; $95 \%$ CI, 1.12 - 9.79) [14]. According to the type of wind instrument (such as playing a woodwind or brass wind), there is also a potential higher risk of developing temporomandibular dysfunction. In addition, based on the study of Lacerda et al., gender, age, and the interaction age and years of instrument practice are also associated with a higher risk of developing the temporomandibular disorder.

\section{Discussion}

This is the first integrative review that evaluates the influence of playing a wind musical instrument on the occurrence of temporomandibular disorders and assesses the most common developed signs and symptoms resulting from short- or long-term practice. In addition, this review specifically investigated the craniofacial effect of playing wind instruments among individuals from different geographic locations. Based on the findings emerging from the included studies in this review, the qualitative results demonstrated that playing a wind instrument is often associated with clinical signs and symptoms (such as facial and temporomandibular pain, headache, tinnitus, teeth grinding, and jaw locking). Furthermore, we found statistically significant risk factors that favor the development of temporomandibular disorders (such as mouthpiece pressure and protrusion distance of the mandible).

Since the early 1950s, several orthodontic experts and investigators have tried to understand the mechanisms involved in playing wind instruments and developing maxillofacial disorders. Firstly, based on cephalometric assessments with trumpet players diagnosed with Class II malocclusion and mandibular retroposition, Parker et al. have shown that to maintain the physical contact between the lips and the mouthpiece, musicians are required to move the mandible forward more than naturally needed [22]. This continuous and non-physiological physical contact could produce an enhanced external pterygoid muscle fatigue and correlated clinical symptoms. Subsequently, Gualtieri et al. had observed a higher prevalence of crepitus or clicking sound in 
the temporomandibular joints among trombone and tuba music players $(31 \%)$ than the control group [23]. Based on cephalometric and teleradiographic appraisals, the authors identified a repetitive pattern of movement of the mandible while musicians are actively playing (mandible moves up and back from rest to playing position), which provides a posterior displacement of the mandibular condyle and increases the likelihood of anterior dislocation of the articular disc [23]. Therefore, these mechanisms resemble possible pathophysiological explanations for the higher prevalence of maxillofacial dysfunction among wind musical instruments.

The included studies reiterate relevant features between systemic disorders and wind instrument players, particularly mental diseases-related consequences. In addition to musculoskeletal and physical conditions, musicians are constantly submitted to an intensive training routine of conditioning and self-improvement, which regularly causes a high prevalence of anxiety, stress, and mental-related complaints [13], [24]-[26]. For instance, one included study observed an elevated prevalence of mental disorders among wind instrument players $(61.4 \%)$, which might emerge as a significant predictor of the development of temporomandibular dysfunction [13]. This is even more worrisome if we consider that training practice typically starts during childhood and adolescence, as young practitioners tend to push themselves beyond their perceived limits to progress and improve their skills [6], [16]. Additionally, during the ongoing coronavirus pandemic, studies have reported a worsening of mental health disorders among amateur and professional musicians, mainly because music classes and training, concerts, and all sort of musical-related entertainment activities were canceled or postponed [27]. Thus, we highlight the need for a comprehensive health care plan for musicians, involving dentistry and orthodontic experts, physicians, psychologists, and other allied health professionals.

Throughout the literature search, we have found an increasing and significant number of studies analyzing the prevalence and risk factors for symptoms of oral disorders, pain in the neck and shoulder, and systemic effects among musicians. However, we noticed that the information intensity associated with oral-related pathologies among individuals who play wind musical instruments is still insufficient. Hence, reports of future studies with a well-designed methodology and evaluation of several variables will be required to elucidate either additional epidemiological or pathophysiological features.

The presented integrative review has several limitations. Firstly, we did not register the review title, neither the review question in any registration platforms (such as PROSPERO and Open Science Frame), as this is not a mandatory and frequently required step for integrative reviews. However, we strictly adhered to a previously defined guideline for performing an integrative review, considering essential process phases (preparing a research question, searching the literature, extracting data from included studies, discussing the results, and adequately presenting overall findings). Secondly, we decided to search for studies only published between 2009 and 2020. Nevertheless, older publications would not modify the trend and main features observed and highlighted in our research. Due to the limited number of included studies, the associated certainty of the evidence is restricted, given that high-quality designed studies were not found in our database search. Notwithstanding, considering the absence of better-designed studies, inferences from observational investigations can help improve health outcomes for the population. Finally, although we have filtered our search by language (English, Spanish, and Portuguese), we believe that any potential additional study published in another language would not significantly change the general findings herein presented.

\section{Conclusions}

Based on this integrative review of ten studies, wind instrument players often report clinical signs and symptoms of temporomandibular dysfunction. In addition, three risk factors were statistically associated with the development of the temporomandibular disorder (mouthpiece pressure, distance of mandible protrusion, and temporomandibular pain). Future high-quality design studies are required to characterize the impact of playing wind instruments on functional 
and oral health status.

\section{References}

[1] L. Zhao and R. Monahan, "Functional assessment of the stomatognathic system," Clinics in Plastic Surgery, Vol. 34, No. 3, Jul. 2007, https://doi.org/10.1016/j.cps.2007.04.003

[2] C. P. Guzmán Valderrábano, A. Durán Gutiérrez, J. R. Hernández Carvallo, and I. G. Valdivia Gómez, "Instrumentos musicales como factor etiológico de maloclusiones," (in Spanish), Revista Mexicana de Ortodoncia, Vol. 6, No. 1, Apr. 2018.

[3] R. L. Gauer and M. J. Semidey, "Diagnosis and treatment of temporomandibular disorders," American family physician, Vol. 91, No. 6, pp. 378-386, Mar. 2015.

[4] Paula Próspero Borelli Bortolleto, Ana Paula Sereni Manfredi Moreira, and Paulo Roberto de Madureira, "Análise dos hábitos parafuncionais e associação com Disfunção das Articulações Temporomandibulares," Revista da Associacao Paulista de Cirurgioes Dentistas, Vol. 67, No. 3, pp. 216-221, 2013.

[5] J. Frias-Bulhosa, "Impactos oro-faciais associados à utilização de instrumentos musicais," Revista Portuguesa de Estomatologia, Medicina Dentária e Cirurgia Maxilofacial, Vol. 53, No. 2, pp. 108116, Apr. 2012, https://doi.org/10.1016/j.rpemd.2011.11.001

[6] M. K. A. van Selms, J. Ahlberg, F. Lobbezoo, and C. M. Visscher, "Evidence-based review on temporomandibular disorders among musicians," Occupational Medicine, Vol. 67, No. 5, pp. 336343, May 2017, https://doi.org/10.1093/occmed/kqx042

[7] A. Steinmetz, A. Zeh, K. S. Delank, and I. Pero, "Symptoms of craniomandibular dysfunction in professional orchestra musicians," Occupational Medicine, Vol. 64, No. 1, pp. 17-22, Dec. 2013, https://doi.org/10.1093/occmed/kqt148

[8] V. A. E. Baadjou, N. A. Roussel, J. A. M. C. F. Verbunt, R. J. E. M. Smeets, and R. A. de Bie, "Systematic review: risk factors for musculoskeletal disorders in musicians," Occupational Medicine, Vol. 66, No. 8, pp. 614-622, May 2016, https://doi.org/10.1093/occmed/kqw052

[9] M. M. Attallah, C. M. Visscher, M. K. A. van Selms, and F. Lobbezoo, "Is there an association between temporomandibular disorders and playing a musical instrument? A review of literature," Journal of Oral Rehabilitation, Vol. 41, No. 7, pp. 532-541, Apr. 2014, https://doi.org/10.1111/joor.12166

[10] C. B. Soares, L. A. K. Hoga, M. Peduzzi, C. Sangaleti, T. Yonekura, and D. R. A. D. Silva, "Integrative review: concepts and methods used in nursing," Revista da Escola de Enfermagem da USP, Vol. 48, No. 2, pp. 335-345, Apr. 2014, https://doi.org/10.1590/s0080-6234201400002000020

[11] M. T. de Souza, M. D. da Silva, and R. de Carvalho, "Integrative review: what is it? How to do it?," Einstein (São Paulo), Vol. 8, No. 1, pp. 102-106, Mar. 2010, https://doi.org/10.1590/s167945082010rw1134

[12] K. S. Lopes de Matos and S. L. Vieira, Pesquisa Educacional: o Prazer de Conhecer, 2 ed. (in Portuguese), Fortaleza: Demócrito Rocha, 2002.

[13] J. Stechman Neto et al., "Ocorrência de sinais e sintomas de disfunção temporomandibular em músicos," Revista da Sociedade Brasileira de Fonoaudiologia, Vol. 14, No. 3, pp. 362-366, 2009, https://doi.org/10.1590/s1516-80342009000300012

[14] A. Nishiyama and E. Tsuchida, "Relationship between wind instrument playing habits and symptoms of temporomandibular disorders in non-professional musicians," The Open Dentistry Journal, Vol. 10, No. 1, pp. 411-416, Aug. 2016, https://doi.org/10.2174/1874210601610010411

[15] M. Pampel, H. A. Jakstat, and O. M. Ahler, "Impact of sound production by wind instruments on the temporomandibular system of male instrumentalists," Work, Vol. 48, No. 1, pp. 27-35, 2014, https://doi.org/10.3233/wor-131621

[16] M. K. A. Selms, J. W. Wiegers, H. A. Meer, J. Ahlberg, F. Lobbezoo, and C. M. Vissche, "Temporomandibular disorders, pain in the neck and shoulder area, and headache among musicians," Journal of Oral Rehabilitation, Vol. 47, No. 2, pp. 132-142, Sep. 2019, https://doi.org/10.1111/joor.12886

[17] J.-Y. Jang, J.-S. Kwon, D. H. Lee, J.-H. Bae, and S. T. Kim, "Clinical signs and subjective symptoms of temporomandibular disorders in instrumentalists," Yonsei Medical Journal, Vol. 57, No. 6, p. 1500, 2016, https://doi.org/10.3349/ymj.2016.57.6.1500

[18] G. E. Leonardi, B. L. Kieling, G. E. da S. Reis, B. B. Leonardi, P. B. H. Sydney, and D. Bonott, "Prevalence of orofacial pain in wind instrument players," Brazilian Journal of Pain, Vol. 3, No. 1, 2020, https://doi.org/10.5935/2595-0118.20200011 
[19] E. Yasuda et al., "Prevalence of temporomandibular disorders among junior high school students who play wind instruments," International Journal of Occupational Medicine and Environmental Health, Vol. 29, No. 1, pp. 69-76, Sep. 2015, https://doi.org/10.13075/ijomeh.1896.00524

[20] M. M. Barbosa, R. S. C. Cunha, and M. G. L. De Oliveira, "Prevalência de desordens temporomadibulares em músicos," Revista Univap, Vol. 22, No. 40, p. 805, Apr. 2017, https://doi.org/10.18066/revistaunivap.v22i40.1624

[21] F. Lacerda, C. Barbosa, S. Pereira, and M. C. Manso, "Estudo de prevalência das disfunções temporomandibulares articulares em estudantes de instrumentos de sopro," Revista Portuguesa de Estomatologia, Medicina Dentária e Cirurgia Maxilofacial, Vol. 56, No. 1, pp. 25-33, Jan. 2015, https://doi.org/10.1016/j.rpemd.2014.11.208

[22] J. H. Parke, "The alameda instrumentalist study," American Journal of Orthodontics, Vol. 43, No. 6, pp. 399-415, Jun. 1957, https://doi.org/10.1016/0002-9416(57)90194-x

[23] P. A. Gualtier, "May Johnny or Janie play the clarinet?," American Journal of Orthodontics, Vol. 76, No. 3, pp. 260-276, Sep. 1979, https://doi.org/10.1016/0002-9416(79)90023-x

[24] P. S. Brito, "Música e Neurociências: O impacto neurofisiológico da rotina do estudante universitário de música," (in Portuguese), Universidade Federal de Pernambuco, Recife, 2019.

[25] R. S. de Almeida, J. de L. Guimarães, and J. Z. de Almeida, "Estresse emocional e sua influência na saúde bucal," (in Portuguese), DêCiência em Foco, Vol. 2, No. 1, pp. 78-102, Jul. 2018.

[26] C. H. R. Bueno and M. L. Castro, "Consequências do estresse na saúde bucal: revisão de literatura," Facit Business and Technology Journal, Vol. 3, No. 19, Art. no. 19, Nov. 2020.

[27] V. Louro, F. dos S. Louro, and P. G. Duarte, "O estresse gerado pela pandemia como risco para adoecimento mental e físico do músico a partir das neurociências cognitivas," Revista Música, Vol. 20, No. 2, pp. 379-396, Dec. 2020, https://doi.org/10.11606/rm.v20i2.178817

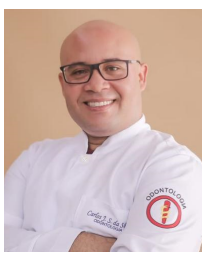

Carlos José Santos da Silva received a bachelor's degree in Public Administration at the State University of Bahia. Current 5th-year Dentistry student at the Faculdade de Tecnologia e Ciências da Bahia. Laboratory odontology technician since 2007.

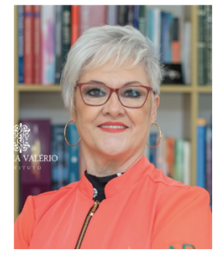

Patrícia Valério received a Doctorate and Post-Doctorate at the Federal University of Minas Gerais, Belo Horizonte, Minas Gerais - Brazil (supported by CNPq and FAPEMIG, respectively). She is a specialist in Jaw Functional Orthopedics, dedicating her life to basic sciences, focused on bone physiology to support the functional orthopedics practice. Invited researcher at Istanbul Technical University and Marmara University in Turkey; Aveiro University in Portugal; Ioannina University in Greece; University El Bosque in Colombia. Speaker in more than 11 countries. Since 2007, teaches JFO at Biofokus (Turkey) and at WSEI (Portugal, 2017).

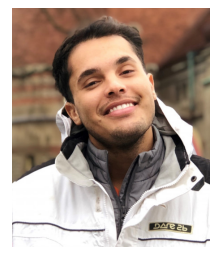

Isral Júnior Borges do Nascimento is a Clinical Pathologist (licensed in Physiology and Biophysics) graduated at the Federal University of Minas Gerais, Brazil. He has spent over a decade being part of cutting-edge research on cardiovascular and cerebrovascular diseases. He has been working with Evidence-based Medicine at Cochrane Sweden, Cochrane Croatia, and University Hospital at the Federal University of Minas Gerais. Recently, Israel has become a Scientific Research Consultant at the World Health Organization. Cochrane member and voluntary translator. CEO First Class Communications.

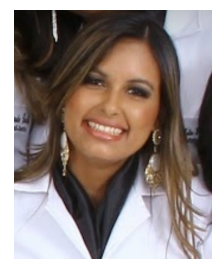

Juliana Araújo da Silva Simoura received her bachelor's degree in dentistry in 2013 at the State University of Feira de Santana and her MSc degree in Collective Health in 2018, focusing on epidemiology of oral diseases. Current professor at the Faculdade de Tecnologia e Ciências da Bahia. 